\title{
The U.S. Dollar and the World Economy: A Critical Review
}

\begin{abstract}
By Kalim Siddiqui ${ }^{*}$
The relative decline of the U.S. as a global economic power is clear, and can be seen in the statistics. However, the U.S. decline is nevertheless a slow one, and carries all sorts of unprecedented dangers for the world. The U.S. is definitely in a less powerful position than previously with respect to production, but it is still successfully siphoning off much of the economic surplus (or surplus value) created in the developing countries via the operations of its multinational corporations and its hegemony over the global financial architecture. With respect to U.S. financial dominance, the key issue becomes the continuation of the dollar as the hegemonic currency, which is currently threatened by the rise of China. This paper intends to critically analyse the performance of the U.S. economy and also the role played by the U.S .dollar in the international payment and in reserve currency. The study will also examine the expansion of Chinese economy and importance of the gradual development of a multicurrency system with the intention of reducing the growing balance of payments deficit putting pressure on a single reserve currency. This study has followed doctrinaire methodology, which includes analytical, descriptive and comparative methods. This article concludes that the U.S. economy is currently suffering from a serious trade deficit and the position of the U.S. dollar is under genuine threat from the renminbi, the renminbi will not be able to replace the U.S. dollar as the global currency for at least the next decade. (JEL E50, 60, F30, G15)
\end{abstract}

Keywords: World Economy, U.S. Dollar and the Renminbi.

\section{Introduction}

The relative decline of the U.S. as a global economic power is clear, and can be seen in the statistics. However, the U.S. decline is nevertheless a slow one, and carries all sorts of unprecedented dangers for the world. The U.S. is definitely in a less powerful position than previously with respect to production, but it is still successfully siphoning off much of the economic surplus (or surplus value) created in the developing countries via the operations of its multinational corporations and its hegemony over the global financial architecture. With respect to U.S. financial dominance, the key issue becomes the continuation of the dollar as the hegemonic currency, which is currently threatened by the rise of China. (Wade 2017, Economist 2015) The U.S. share of the global domestic product is estimated at less

\footnotetext{
*Senior Lecturer, Department of Accounting, Finance and Economics, University of Huddersfield, UK.
} 
than 20\%, while U.S.-based companies control about half of the world's wealth (World Bank 2017).

Of course, these facts show us a very complex picture of the contemporary world. A recent study by Bullard et al. (2017) points out that the U.S. economy is still the world's largest economy and, according to them, between 2008-15 there was an average annual shortfall of $20 \%$ in fixed capital investment due to the 2008 crisis, which adversely impacted on GDP growth by an average of 10\% (Bullard et al. 2017). Needless to say, the U.S. has by far the largest military in the world. It controls - largely through the role played by its military sector in technological development - the most advanced technologies in the world (Harvey 2005).

For major G7 economies, the average growth rates experienced were all over $3 \%$ between 1960-80; however, in 2016-17, U.S. growth was 1.7\%, the Eurozone area saw 1.8\% growth, and Japan, 1.1\% (World Bank 2017: 4, Table 1.1). Wien (2010) commented about the U.S. economic decline in key areas like, the "return on investment" from an estimated $15 \%$ in the post-war period to $10 \%$ by the end of the 1980s; by the end of 1990s, it was said that the return was only "5 percent and few would put money at risk for that reward" (Wien 2010).

This paper intends to examine the performance of the U.S. economy and also the role played by the U.S. dollar in the international payment and in reserve currency. The U.S. dollar is, at present, the dominant reserve currency of the country's central banks. The U.S. Treasuries market is the most liquid financial market in the world, which makes Treasures an attractive investment for holding central bank reserves. The U.S. dollar is also the dominant currency for invoicing international trade and is also used in denominating the majority of foreign debt securities (Fine 2013). The study will also examine the expansion of Chinese economy and importance of the gradual development of a multicurrency system with the intention of reducing the growing balance of payments deficit and lessening of pressure on a single reserve currency. A multicurrency reserve would even help developing countries to diversify their foreign exchange currency holdings; hence, should a country accumulate a huge amount of U.S. dollars and find that confidence in the dollar declines, then they can merely switch to other reserve currencies. This reduces the demand for single reserve currency.

This paper also aims to analyse the Chinese currency and its potential to become an international reserve currency. However, China needs to improve the efficiency of its financial sector and financial market (Subacchi 2016). The challenges will be whether increased demand for the renminbi would lead to its appreciation and consequent loss of export competitiveness in the global markets. This study has followed doctrinaire methodology, which includes analytical, descriptive and comparative methods. The research is drawn from the use of past documents to understand the subject area and in the process it becomes evident that the methods utilized depend not only upon the researchers' perspective, but also on the time and available resources.

The relative strength of the U.S. economy supports the value of its currency. In fact, this was an important reason for the US dollar emerging as the most powerful currency after World War II. At the end of the World War II, the US accounted for half of the world's GDP and with Europe and Japan destroyed by 
the war, the US was the only country with a developed manufacturing sector to produce goods needed by the consumers. As Western Europe and Japan began to recover from the war, the US relative economic strength started to decline. By the 1980s, West Europe and Japan caught up with the US in the terms of productivity. In the 1990s, the dominance has remained due to the rising amount of US dollar debt owed by domestic and foreign borrowers and creditors in countries in the rest of the world.

Despite the slowdown of the U.S. economy in recent decades, more than onethird of the world's gross domestic product still comes from countries that peg their currencies to the dollar; indeed this includes seven countries that have adopted the U.S. dollar as their own. Furthermore, more than eighty-five countries maintain their currencies in a tight trading range relative to the dollar. In fact, the U.S. GDP makes up only $25 \%$ of the global GDP and U.S. trade volume in only $15 \%$ of the world's total trade in 2017. But still the U.S. dollar remains the predominant currency used in world trade and financial transactions. For example, the U.S. dollar makes up nearly $63 \%$ of central banks' reserve currency holdings, against 17\% for the euro and 2\% for the yen (Siddiqui 2018a, World Bank 2017). In the foreign exchange market, $90 \%$ of forex trading involves the U.S. dollar. The dollar is of course just one of the world's currencies, but most of these currencies are only used inside their own countries. Theoretically, any one of them could replace the dollar as the world's currency, but this is unlikely as they are generally not widely traded. At present, nearly $40 \%$ of the world's debt is issued in the U.S. dollars (World Bank 2017, Willett and Chiu 2012).

The history of international reserve currencies shows that there is a tendency in the past for one currency to dominate global trade and finance, and any change to the status quo is often reflected in shifts in its economy and global power politics (Harvey 2005). This means that there has been a strong incentive to choose a currency that other trading countries are able to accept and use for international transactions. However, a dominant currency can lose its hegemony to another due to changing economic and political dynamics. For example, the British Pound Sterling was a leading international currency before World War I - more precisely between 1860 and 1914 - when more than $60 \%$ of world trade was invoiced and settled in Pounds Sterling, and a similar trend was seen in the holdings in the global foreign exchange reserve. Once Britain became colonial power, it encouraged colonial administration to use Pound Sterling and thanks to the associated favourable policy of support, Sterling then flourished. (Kaldor 1971) In 1914, Britain stopped using the gold standard but returned to it in 1925 at a prewar parity under pressure from British financial capital, which wanted such parity; at that time, Britain had colonies to support such moves, but such alternatives were not available after the war, so the Pound Sterling was over-valued and Britain started facing balance of payment problems. To extricate itself from this, Britain imposed wage deflation and reduction in domestic absorption on its workers so that its exports would be cheaper and imports more expensive. The then strong trade unions did not accept this and called for a general strike in 1926, soon after Britain returned to gold standard. The current situation differs from earlier periods 
because the advanced economies do not have direct colonial possessions (Siddiqui 2019b).

In the beginnings of World War I, the balance of Sterling accounted for less than half of total official foreign exchange holdings, while the French Franc accounted for about a third and the German Mark about one-sixth. Between the 1920s and 1930s, these two currencies (Pound and Franc), along with the U.S. dollar, dominated the demand for international reserve currencies. Historically, very large UK's current account deficits have been sustained for long periods of time, as seen during the late 19th century. The UK was also exporting huge amounts of capital to countries such as Australia, Canada and Argentina. Some critics were worried that UK investors were lending and exporting capital at the neglect of the domestic markets. This was primarily due to the lack of higher returns in the domestic economy (Siddiqui 2019a, Kaldor 1971).

During World War I, the UK economy understandably experienced a deep crisis and its current account and fiscal deficits and external debts rose sharply. These developments affected the British Pound adversely. Soon after World War I, the U.S. dollar took over as the leading international currency, but it was not until end of the World War II (i.e., 26 years later) that the dollar became the dominant international currency, replacing the Pound Sterling as the principal international currency (Kaldor 1971). At present, similar situation can be seen in the U.S. economy, where the U.S. trade share in the global economy has declined significantly; nevertheless, other countries are still using the U.S. dollar as an invoicing currency, which keeps the ex-post prices of goods similar to those of its competitors, and further provides hedging benefits. Safe heaven depositors have not been influenced by recent developments in the US economy, even after the Standard and Poor downgraded the US credit ratings in August 2011.

Currently, the U.S. economy is experiencing deep structural difficulties. The question facing other countries' governments now is whether they will go on buying and holding U.S. securities in large amounts. For more than six decades the U.S. has maintained its financial hegemony (Fine 2013), where no other asset was seen as attractive as U.S. dollar by the overseas investors; however, things are now changing, with the Eurozone, for instance, providing as large a liquid market as the U.S. The Euro economy is the same size as that of the U.S., but at present accounts for a larger share of world trade.

Since the euro emerged as the single currency of the Eurozone countries, a single euro has consolidated, rather than fragmented, national currencies (prior to 1999). It seems the euro has emerged as a second important useful currency to be used as a reserve by the country's central banks. In 2010, the euro's share as a reserve currency was $26 \%$, as compared to $61.8 \%$ for the U.S. dollar for the same year (Siddiqui 2019b). In 2010, East Asian currency traders conducted 93\% of their transactions in foreign exchange markets, as these markets also happened to have seen the largest shares in global growth. All these factors have boosted the demand for U.S. dollars (Wolf 2008, Harvey 2005).

Further, in reference to debt, the U.S. official indicates that as a share of GDP, U.S. debt has greatly increased in recent years. The proportion of debt to GDP may drop due to government surplus, inflation or growth in GDP. As of October 
2018, the US public debt stood at $\$ 15.8$ trillion; at the same time, intragovernmental holdings stood at $\$ 5.8$ trillion. Further, in 2017, U.S. debt was about $77 \%$ of its GDP which was the 43rd highest in the world. By 2028, the ratio would be $100 \%$, or even higher if present policies will be extended past the scheduled expiration date. Further, by December 2017 45\% (\$9.3 trillion) was held by foreign investors, with China having the largest share of $\$ 1.18$ trillion, followed by Japan at $\$ 1.06$ trillion. (OECD 2019, Willett and Chiu 2012)

The use of the U.S. dollar as an international reserve currency heightens the so-called Triffin dilemma. With increasing trade there are also demands for international reserve increases. Hence, the reserve-issuing country needs to continue to run a balance of payments deficit in order to meet the increasing demand for its currency; as a consequence, the reserve-issuing country's external debts rise sharply. According to the researchers, an international currency must satisfy three key criteria, which are: medium of exchange, unit of account, and store of value (Patnaik 2009). In the short term, it appears that the U.S. Dollar and euro are likely to remain the dominant international reserve currencies. The greatest challenge is currently seen to be a lack of dynamism within the eurozone economy, and it is unlikely the euro will ever represent an alternative to U.S. Treasury, also in part due to the eurozone's current economic crisis, especially in the southern EU countries. The Japanese yen, which had high levels of foreign exchange reserve of $8 \%$ in 1990, soon declined due to the long-term stagnation of the Japanese economy; in 2010, the reserve in the yen was merely $3.7 \%$.

The Chinese renminbi could emerge as the new international currency with the country's growing economy and trade. The Chinese economy has increased its share in the global economy. In the coming decades, it is hoped that China's economy will take over that of the United States. China has increased reliance on international trade, with both its exports and imports consistently rising; it is expected that its trade will grow further in the future. China's export baskets include manufacture products and its currency could be used for global exchange.

Flexible exchange rates and free capital movement have been unable to keep the world economy stable. The emerging economies have built up massive foreign exchange reserves principally in order to protect themselves from panic capital withdrawals (Siddiqui 2018b), as seen during the 1997 East Asian crisis and again after the 2008 financial crisis. Such sudden withdrawal of capital proved to be costly in terms of their investment, economic growth and overall development. This uncertainty also adds to global imbalances. Lee (2014: 43) noted: "The fast growing economies of developing Asia are providing an important source of global production and demand. Asia's emerging and developing economies maintained an average annual growth rate of $6.8 \%$ over 2000-10. In 2010, Asia (including Japan) accounted for about $27 \%$ of global GDP, up from mere $12 \%$ in 1960. By comparison, in 2010, the United States contributed $23.1 \%$ and the European Union (EU) $25.8 \%$ to the world GDP".

The emerging economies have kept reserves in dollar denominated assets. The continuous rise in foreign reserves in foreign countries has led to an increase in demand for U.S. financial assets, which is tied to the ever-rising inflow of funds into the U.S. financial system from abroad, which encourages asset prices bubbles; 
also, excessive reserve accumulation overseas is due to developing economies trying to self-ensure against possible speculative currency attacks. This caution is due to the East Asian crisis of 1997, and the desire to guard against sudden investment collapse or to keep currency from appreciating as this could adversely affect export competitiveness (Wade 2017). A large number of emerging market economies borrowed heavily in dollars when American interest rates were at rockbottom levels (Huang and Kishor 2019, Siddiqui 2017). The result was creditdriven growth, which starts to look fragile when - as now - the Federal Reserve is raising interest rates and the U.S. dollar is strengthening (Siddiqui 2018c).

Despite some of these countries' efforts to build-up foreign exchange reserves over the past decades, the shortages of US dollars as capital inflows into these economies resulted in a reversal of capital flows into developed economies. All these developments led to an increased cost of borrowing in the dollar. The Stiglitz Commission (United Nations 2009) argued for the creation of a new global reserve system based on Special Drawing Rights (SDRs). The Commission report recommended that during recession the role of the SDR should be increased through IMF lending to those countries in need of short-term finance (Stiglitz and Greenwald 2010).

Since the 2008 crisis, the interest rates in the advanced economies have been maintained at almost zero levels in order to revive their economies, which meant that the flow of capital from their economies to the emerging economies became more profitable. Such capital flows have taken the form of equities and loans. Therefore, if the currencies in emerging economies depreciate, then asset holders from the advanced economies will be affected (Siddiqui 2016a,b). Any depreciation of the local currency will thus start panic and result in capital flight from the emerging economies. This means international capital is not interested to see depreciation take place (Patnaik 2009).

\section{Performance of the U.S. Economy}

The current account provides an overview of transactions between a country and its foreign trading partners resulting from the purchase and sale of goods and services produced in the current period. If the United States has a current account surplus, this means that America is selling more goods and services to foreign markets than they import goods purchased from foreign markets. Typically, since 1996, the U.S. has a negative current account balance, or current account deficit (See Figure 1), while, Germany, Japan and China have current account surplus. When there is a current account deficit, the United States must borrow the liabilities to pay for goods and services purchased from abroad. The external debt rises as a result of current account deficits. However, exchange rate changes may not be adjusted according to the direction of balance of payments. If the current account is in deficit but there is also a large amount of capital inflow in capital account surplus, the currency will not devalue but will rather appreciate, thereby exacerbating the balance of payments deficit. If the balance of payments deficit is caused by a current account deficit, it will inevitably lead to fewer jobs in export- 
related sectors and a downturn in the economy. If the balance of payments deficit is caused by capital account and financial account deficit, however, this would mean a lot of capital outflows and a tight supply of domestic capital, which would result in a rise in interest rates and a decline in the economy.

According to Amadeo (2018), the main contributors to the deficit are consumer products where, in 2017, the U.S. imported consumer products worth $\$ 602$ billion, while exports totalled $\$ 198$ billion. This could be explained by the decline in competitiveness of U.S. products which was largely the result of the devaluation of the Chinese yuan, making Chinese products cheaper than U.S. products. In an effort to bridge this gap, President Trump enacted his policy of protectionism measures (Siddiqui 2018a), in particular imposing tariffs against the imports from China and Mexico (Amadeo 2018).

Figure 1. Current Account Balance, Total, \% of GDP, 1996-2018 (Source: Main Economic Indicators: Balance of Payments)

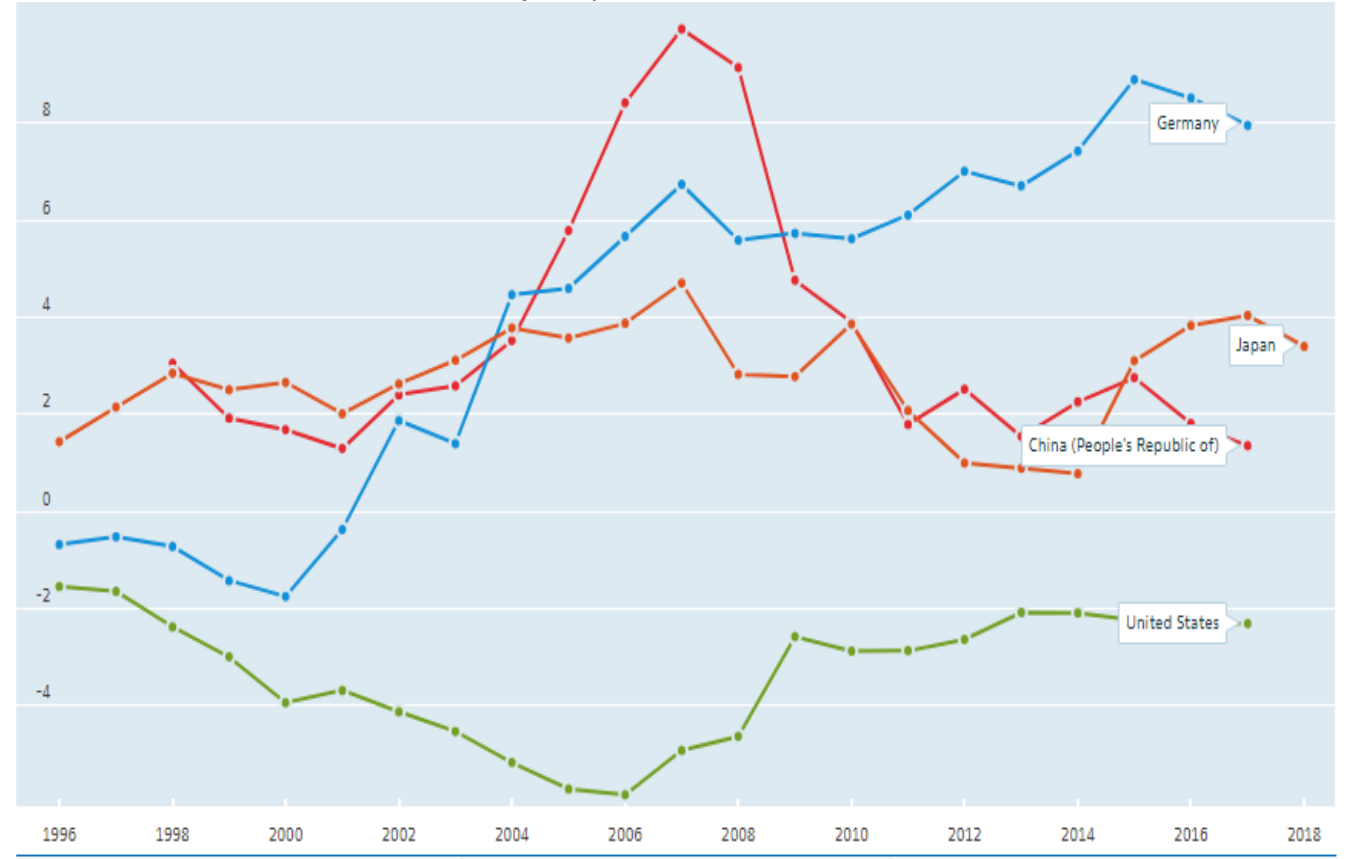

Source: OECD Retrieved from https://data.oecd.org/trade/current-account-balance.htm [Accessed 10 February 2019]. 
Figure 2. United States Long Term Interest Rates, Total, \% per Annum, May 1998November 2018

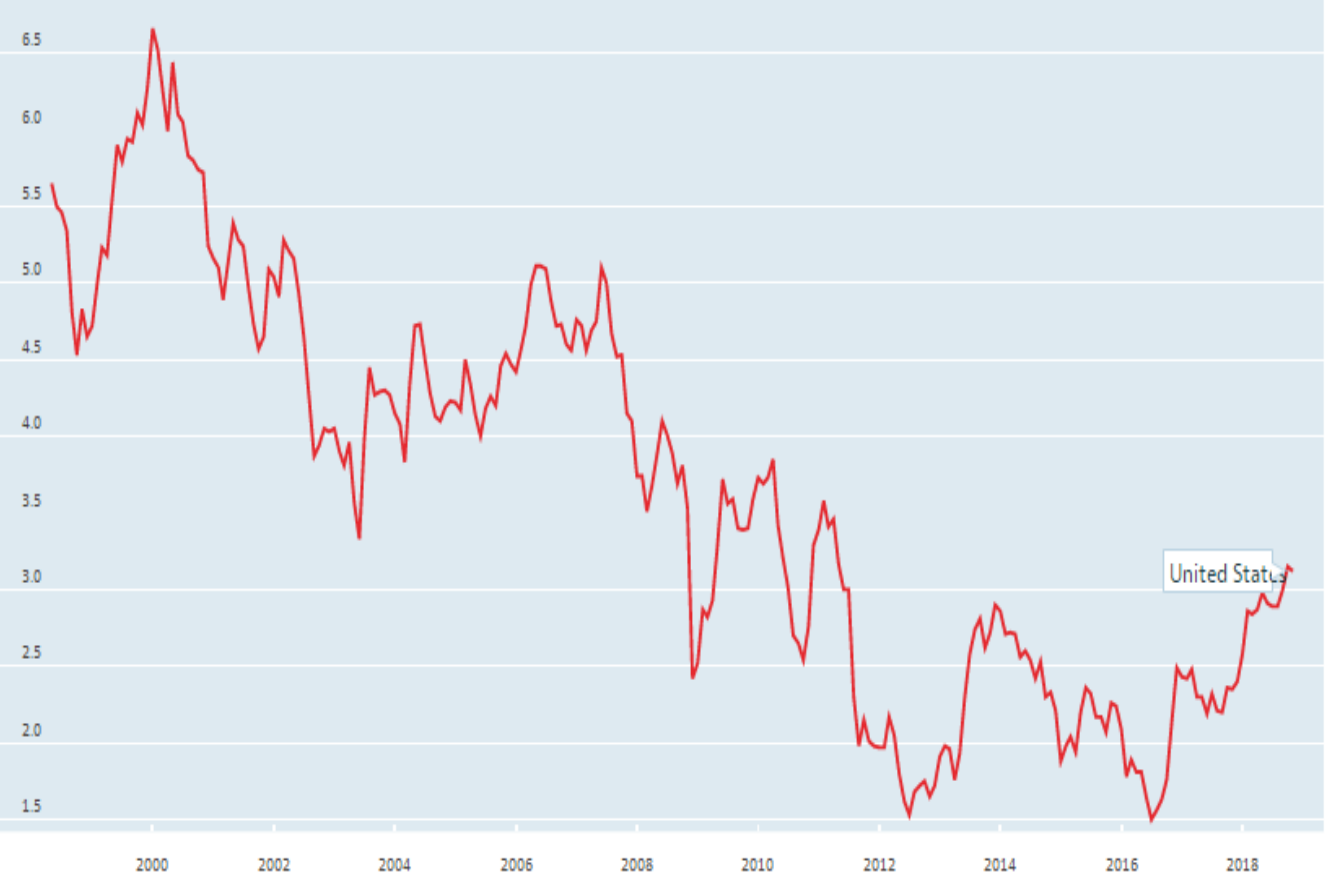

Source: OECD Data. Retrieved from https://data.oecd.org/interest/long-term-interest-rates.htm [Accessed 10 February 2019].

Figure 3. Real GDP Long-term Forecast, Total, Million US Dollars, 2020 - 2040

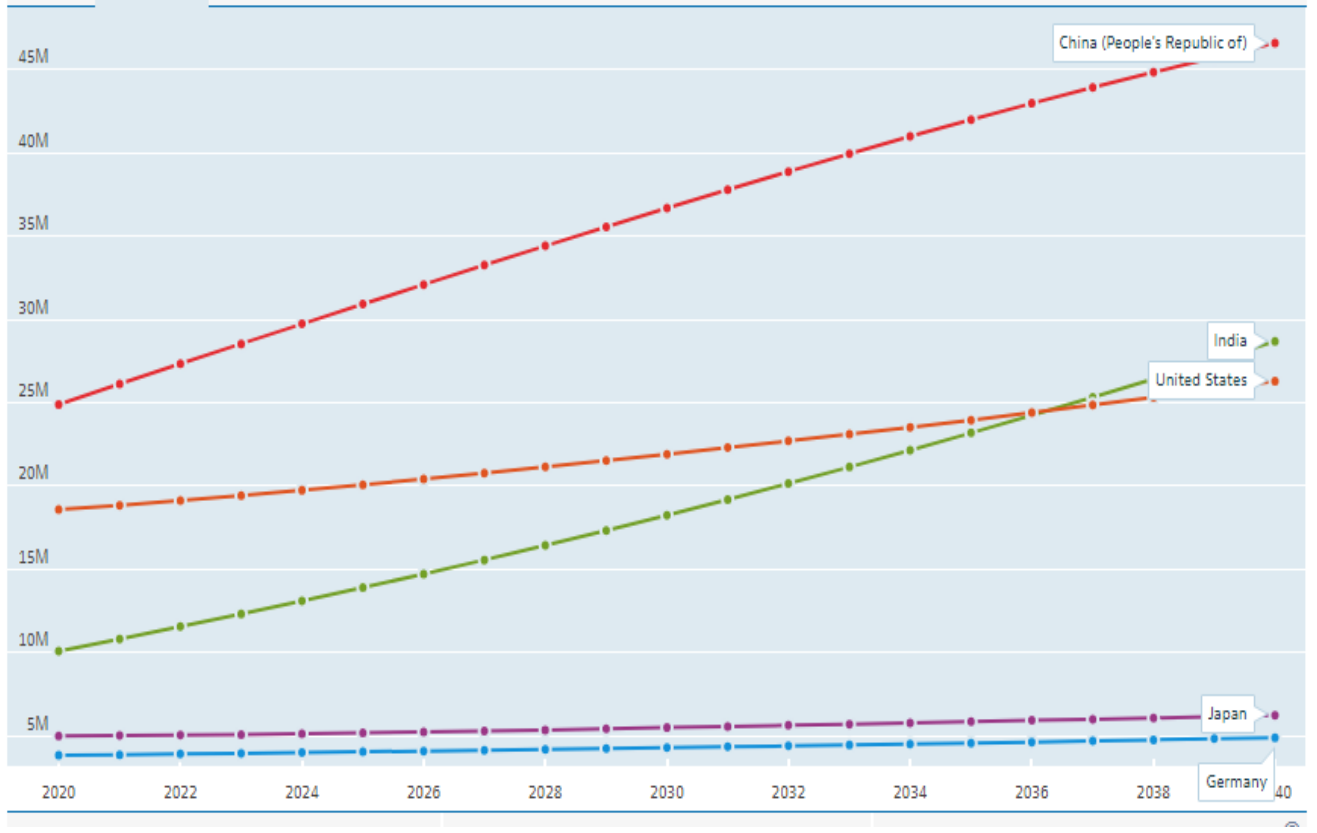

Source: OECD Economic Outlook: Statistics and Projections: Long-term Baseline Projections. Retrieved from https://data.oecd.org/gdp/real-gdp-long-term-forecast.htm. [Accessed 2 March 2019]. 
China, Japan and Germany are willing to go on buying enough U.S. Treasuries and other dollar assets to finance U.S. deficits and sustain the U.S. dollar. In response to the bursting of the financial bubble around 2000, the Federal Reserve cut U.S. interest rates 13 times in two years, from $6.5 \%$ to $3.5 \%$ (see Figure 2). Low interest rates have prompted Americans to invest their savings in assets and banks to lend too much, contributing directly to the continued expansion of the U.S. housing bubble.

Once the dollar loses its status as an international currency, there is no doubt that it would depreciate substantially. The United States will be unable to repay its external debt. China, as the largest of American creditors, will lose a lot of money. Transparency in U.S. financial markets and predictability and credibility in monetary policy have strengthened the dollar's position. Unlike many other economies, the current structure of the U.S. economy also allows it to reasonably tolerate a persistent trade deficit, so the dollar will remain the main foreign exchange reserve for a long time.

As the crisis deepened in the 1980s and 1990s, neoliberal capitalism was adopted in the major capitalist countries. This led to undo the gains of the previous decades, especially in terms of income distribution. For instance, in the U.S. the income share of the top income group (1\%) declined from $29 \%$ in 1929 to $8 \%$ in 1970 and remained about same until 1979, while the lower and middle income group experienced a greater rise in their incomes. In contrast, the neoliberal regime pursued since the 1980s reversed the redistributive policy. For instance, the income share of the top $1 \%$ in the US then rose very sharply to $23 \%$ by 2008 (Wade 2009).

Ten years ago, the financial crisis in the United States led to a global economic crisis in 2008. This financial crisis was caused by the exposure of risks in the U.S. house market, which led to a nearly vertical downward shift in the U.S. dollar index. Emerging economies have been affected by the severity of the global economic financial shocks because the current global reserve system fails to ensure adequate international liquidity (Lee 2014). The global financial crisis of 2008 showed weaknesses in the current monetary system and it has contributed to global financial instability and ultimately adversely affected the global economy. For developing countries, which heavily rely on trade and capital inflows for their economic growth, the failure of the global reserve system with insufficient international liquidity led them to witness difficulties in the aftermath of the global financial crisis (Costigan et al. 2017).

In fact, the rate of accumulation responds to the rate of profits in the economy when profit rate increases, meaning higher expected returns from expanding capital stocks. The profit rate fell during the 2008 crisis, but after 2013 profit rates rose again, but have fallen slightly again since 2014. The recovery of 2012-14 was associated with debt-financed consumer spending, which is not sustainable in the long run. The 2014 recovery took place when consumer spending accelerated while investment in the economy slowed, government spending also declined in real terms over the period, exerting adverse pressure on output growth. During this period, U.S. imports grew faster than exports, therefore the biggest factor to have contributed to the recent growth in U.S. GDP is household consumer spending, 
i.e., contributing $81 \%$ to its increase in the period 2014-17 (Kotz 2018), while investment slowed to $2.1 \%$, contributing only $16 \%$ to growth in GDP growth over the same period. As Kotz argues that "The current structural crisis has taken the form of stubborn stagnation despite unprecedented monetary stimulus, with slow economic growth, a low rate of capital accumulation, stagnating real wages and worsening economic insecurity for working people- conditions that have helped to produce new political polarization" (Kotz 2018: 30).

The high dollar, and indeed other factors, had led to an extraordinary decrease in the manufacturing competitiveness of the U.S. (Glyn 2005). The 'strong dollar' policy seen in the 1990s had proved to be more important in terms of attracting capital for the 'new economy'. It was observed that the overseas purchase of U.S. assets, including assets and bonds, rose sharply (i.e., four-fold) between 1989 and 2000. The massive capital inflow was due to foreign investors seeing this as an excellent opportunity to make higher profits that the latest US technology was expected to bring. More than a decade ago, Krugman (2007: 437) noted, "The United States has a remarkably large current amount deficit, both in absolute terms and as a share of GDP. At the moment the country is not having any difficulty attracting capital inflows sufficient to finance this deficit, but many observers nonetheless find that deficit worrisome. This worriers see an ominous resemblance between the current U.S. situation and that of developing countries that also went through periods during which capital flows easily financed large current deficits, then experienced 'sudden stops' in which capital inflows abruptly ceased, the currency plunged, and the economy experienced a major setback".

The widening gap between U.S. economic and financial power is creating difficulties for the rest of the world. This is because the costs of dollar dominance are beginning to outweigh the so-called benefits. The U.S. share of global merchandise imports declined from $16 \%$ in 2005 to $13 \%$ in 2016. The US was the biggest export market for only 32 countries in 2016, which declined from $44 \%$ in 1995, while for China this has risen from 2 to $43 \%$ for the same period (Economist 2015). Bernanke's 'saving-glut' thesis, where he argued that U.S. overspending caused the U.S. trade deficit, was due to this the money flowing into the U.S. market from other countries through its capital account. This would lead to credit expansion and lower interest rates, making it attractive for U.S. consumers to overspend, and as a result U.S. household consumption increased global demands. Here it is being emphasised that the U.S. trade deficit gave rise to excessive global savings. Until this issue is addressed, reducing global imbalances by raising U.S. savings would lead to a global slump and, ultimately, recession. Bernanke also argued that high saving rates in surplus countries, especially in East Asian countries, are due to historical, cultural and demographic factors, while others pointed out that the East Asian crisis has been an important reason for such behaviour. Others emphasise the fact that excessive global savings are due to structural causes and cannot be corrected simply by these measures (Wade 2017).

In recent years, we find there has been an upward shift among the foreign investors who would like to invest in U.S. assets. As long their demands to invest in U.S. dollars of their accumulated wealth exist, this will lead to the generation of large capital inflows into the U.S. economy. The official statistics show a 
substantial role of overseas capital in financing the US current account deficit, but private bond purchases also play a large role as well. The sharp rise in the U.S.. Treasury Bond yields the fact that the interest rates set by the U.S. Treasury have risen from $1.86 \%$ in 2017 to $2.84 \%$ in 2018, after Trump became US President. In 2016 , U.S. economic growth was $1.5 \%$, while the EU's growth was $2 \%$ and China's was $6.7 \%$ for the same period. In 2017, U.S. economic growth was $2.3 \%$, while the EU's average growth was $2.5 \%$, and China's, $6.9 \%$. There seems to be a strong correlation between the growth in U.S. output and the percentage of net fixed investment in the U.S., meaning that in the long term it would not be possible for the U.S. economy to accelerate without an increase in net fixed investment. For example, in 1966, during the long-term boom, the U.S. net fixed investment was $11.3 \%$ of U.S. GDP, but in 1978 U.S. net fixed investment was $10.5 \%$ of U.S. GDP. In 1984, this same figure was $9.2 \%$, then $8.3 \%$ in $1999,7.9 \%$ in 2006 and, in 2017, 4.2\% (Kotz 2018).

The U.S. power reached unprecedented levels at the end of World War II. From the 1960s, however, this dominance started to decline in what was then known as the "loss of China" and as Europe and Japan began to recover from the war and the post-war decolonisation in Africa and Asia moved towards national sovereignty within former European colonies. By the 1970s, the global economy was becoming tripolar: North America, Europe, and Japan. In the last decade, there has been further erosion due to rise of China. However, despite the dramatic transformation in China and the rise of its share in the global economy, and indeed its economy emerging as the second largest worldwide, China remains a poor country whose average income is quite low compared to the developed economies (Siddiqui 2015).

Securitisation is an issue related to collateralised debt obligations (CDOs) by banks which began to take off in the late 1980s and became increasingly prevalent in the run-up to this 2008 crisis. CDOs are created from portfolios of debt pooled together by banks, the ownership of which is transferred to a "special purpose vehicle" (SPV), a temporary company formed for that purpose. This SPV then issues bonds which are sold on to investors. The process is dubbed securitisation because bonds are an example of a security (a tradable financial asset). Essentially, the loan repayments act as a stream of income to the ultimate investors, while, for the bank, the debt is sold on, recouping the cash and allowing it to issue more loans. There are, in addition, lucrative fees available to those overseeing the process. Prior to 2007, the riskiest "tranches" of the bonds issued by SPVs, and hence the most attractive to speculators, often included large numbers of subprime mortgages. The amount of CDOs issued globally rose from $\$ 68$ billion in 2000 to \$521 billion in 2006 (Norfield 2016: 140). As a recent European parliament report put it: "Securitisation amplified the crisis by contributing to lengthening the intermediation chain, by creating conditions for incentives and interests between participants in the securitisation chain to be misaligned, by increasing the reliance on mathematical models and on external risk assessments and, finally, by increasing both individual and systemic bank risks" (Delivorias 2016: 14).

Moreover, through securitisation there has been an explosive growth in derivatives. These consist of assets that change in value depending on what 
happens to some underlying asset. For instance, a "credit default swap" compensates the holder in the event of a specific debt defaulting, in return for which they pay a small regular fee to the counterparty. This can be a useful form of insurance, "hedging" against a risk. However, derivatives can be bought and sold for purely speculative reasons by people who are not exposed to the underlying risk and simply wish to gamble on whether or not something will happen. In the run-up to the crisis, the derivatives market was dominated by interest rate contracts (which pay out as rates move), followed by CDSs. Again, the market in derivatives has not recovered to the peak levels seen immediately prior to the collapse of Lehman Brothers in 2008, but nor has the growth been entirely reversed. In the first half of 2016, the gross market value of "over-thecounter" derivatives (the money required to replace them at market prices) still stood at \$12,690 billion, roughly where it was in early 2007 (Delivorias 2016: 14).

The expansion of credit generally helped both to conceal and to defer capitalism's problems in the period from the early 1980s, as part of a system sometimes dubbed "privatised Keynesianism", but only at the expense of creating a grotesquely oversized financial system that would ultimately explode into crisis. The fact that the long depression began in the field of finance led many commentators to identify it as simply a financial crisis. (Fine 2013, Keynes 1980) After the 2008 financial and economic crisis, the U.S. Federal Reserve, the Bank of England and the European Central Bank launched quantitative easing programmes or, in the case of the Bank of Japan, expanded an existing programme. Quantitative easing involves central banks electronically creating money and using it to purchase assets from banks and other financial institutions, in particular acquiring government bonds. Doing so has two effects. First, it floods the banking system with liquidity, supposedly encouraging lending. Second, it drives up the price of bonds. Bonds pay a fixed income at regular intervals, so, if they increase in price, their "yield", the return on the investment relative to the price, tends to fall. Lower yields mean lower borrowing costs. Rapid accumulation takes place in conditions in which investors believe that production will be profitable. Instead, money was either squirrelled away by the banks or streamed into financial investments, though often high-yielding, risky investments.

Despite the persistence of high levels of sovereign debt in the U.S., no country is willing to challenge the dollar as the representative international currency. As Patnaik notes, any alternative to the dollar as an international currency in the current set-up will need a country to challenge the status quo. He argues that the fall in the value of the dollar in terms of oil could lead to the decline, and finally replacement, of the dollar. At present, there is no attempt nor, it seems, any interest among major dollar holders or among top major economies to seek an alternative. Currently, the major creditors to the U.S., namely China, Japan, Germany and oil exporter Middle Eastern countries, rely heavily on the U.S. markets to prop up their own domestic demand and economy. In the U.S., real wages have fallen since 2008 but domestic demand has continued to grow thanks to household borrowing and domestic and international sources (Patnaik 2009).

The U.S. government has the privilege of paying its debts in its own currency rather than in some other currency. This means that this eases pressure on the U.S. 
to reduce deficits and regulate its banks. As Wade (2009: 545) notes: "The U.S. government's privilege of paying its debts in its own currency rather than in someone else's softens the pressure on it to cut its deficits and get its banks working. The U.S. central bank can just print even more than it has been doing, reducing the pressures for adjustment and raising the potential for a later inflationary surge. The outcome could be stagflation in the USA and damage to countries that hold dollar assets in their foreign exchange reserves."

The U.S. dollar reserve constitutes up to $70 \%$ of the world's foreign exchange reserve. The rapid expansion of the dollar by the U.S. did not lead to hyperinflation in the country. This large additional amount of dollars is being used to boost foreign exchange reserves in emerging economies. Furthermore, huge amounts of U.S. dollars are used in the trade of mineral, oil, gas, and agricultural commodities. The prices of these commodities fluctuate. The countries who import these commodities in large quantities will thus be affected by the rise in price of the U.S. dollar due to imported oil prices. As D'Arista (2009: 634) argues "the key currency status of the dollar appeared to offer significant advantages for the USA, questions about its sustainability have been raised almost since its inception. Any country that issues the global medium of exchange will experience capital inflows and the resulting investments in its credit instruments will increase the availability of credit and allow its residence to spend more and save less. But the steady stream of capital inflows can only continue if the key currency country is able or willing to run the trade deficits that allow other countries to earn the currency they hold as international reserves. Over time, growing imbalances between the external debt of the key currency country and the surpluses of other countries tend to push the system to breaking point. The ballooning internal debt of the reserve currency country - particularly of its household sector - strains its capacity to import and undermines the value of its currency both literally and in terms of its role in the global economy".

According to D'Arista, (2009) the functions for the dollar required that dollar/gold exchange rate be fixed and unchangeable, but in the absence of rival currencies convertible into gold ensured that the dollar would also emerge as an international medium of exchange used in transactions between third countries and an international store of value. Further D'Arista (2009: 641) argues: "Dollar reserves had to be invested in U.S. financial assets to earn interest and earnings on reserves augmented the supply, the amount of investments in the U.S. financial assets also grows. Private dollar holdings were also returned to the U.S. and held as working balances with US banks to pay for trade with the U.S. and the third country. Surplus private funds were invested in time deposits or money market assets or Treasury bills. In time the return flow of dollars to the U.S. provided more credits than its economy could use. The outcome was lower U.S. interest rates, economic expansion and a rising rate of inflation. Excessive inflows also encouraged an even larger volume of capital outflows by the U.S. residence that put pressure on dollar exchange rate".

Keynes' proposed in 1944 that international clearing was the key problem in the international system due to lack of liquidity. He viewed the need to make a system that would favour expansion rather than contraction and ultimately would 
not restrain domestic policy. He opposed the idea of building a system which relies on one dominant currency as reserve assets to minimise the governmental influence and prevent the collapse of foreign national reserves as occurred in 1928. His suggestion was that the accounts of both debtors and creditors would be interest-bearing so that the burden of adjustment would be shared by both countries. (Keynes 1980) For instance, creditor countries would make deposits of the current account surpluses they did not wish to spend and thus create an additional supply of funds for debtor countries to borrow. However, his plan was rejected then by the US. (D'Arista 2009)

Any other country pursuing such a strategy of huge fiscal deficit would witness an outflow of finance as the "investors' confidence" in that country would be undermined. However, the U.S. dollar is still considered "as good as gold". This is due to a number of reasons, including the home base of global finance itself and its global military domination.

World currency can be divided into three distinct categories: 1) advanced economy currencies, e.g., the U.S. dollar was considered as good as gold by other investors and asset holders; 2) other advanced economies' currencies such as the euro, pound sterling; and 3) developing countries' currencies, which were expected to depreciate over time. When India wants to buy a commodity from South Africa, then India first exchanges Indian rupees for U.S. dollar and uses these dollars for payment. However, when a U.S. firm buys something from India, then it can use own national currency (i.e. dollar) for the payment.

Since the 2008 crisis, the interest rates in the advanced economies have been maintained at almost zero levels in order to revive their economies, which meant that the flow of capital from their economies to the emerging economies became more profitable. Such capital flows have taken the form of equities and loans. Therefore, if the currencies in emerging economies depreciate, then asset holders from the advanced economies will be affected. Any depreciation of the local currency will thus start panic and result in capital flight from the emerging economies. This means international capital is not interested to see depreciation take place.

\section{The Performance of the Chinese Economy}

The Chinese economy is now the world's second-largest economy. It is also the second-largest global trader and currently holds the largest amount of foreign exchange reserves. In recent years, the Chinese economy has accounted for more than one-fifth of incremental demand worldwide. The question also arises as to whether the greater use of the renminbi as an international currency is directly associated with the future of the US dollar.

China has, over the last three decades, enjoyed massive growth to become the leading economy in the world by nominal GDP (See Figure 3). As noted by the World Bank (2017), since the introduction of economic reforms in 1978, China has experienced increased industrialisation which made construction and industry the main contributors to GDP. However, in later years, the tertiary sector has 
become the main GDP contributor, accounting for about $46.1 \%$, while the secondary sector represented $45.0 \%$ of total output. Up to 2015 , China had remained the fastest growing economy worldwide, reporting growth rates of about $10 \%$ per annum. In 2017, China had a GDP of \$23.12 trillion, representing an increase of $6.8 \%$ from the previous year (Amedeo 2018). According to the World Bank (2017), China's GDP accounts for about 33\% of global growth.

Since 1980s, the rapid growth of China's share in the global economy has risen sharply and the whole East Asian region has witnessed its highest growth rates. If the region is integrated into a free trade zone and these countries use their own currencies, this will have an adverse impact on U.S. interest, including the use of dollar as a foreign exchange. To safeguard dollar hegemony, the U.S. has, accordingly, been active in the region. (Siddiqui 2015) The last four decades of rapid growth in China has tremendously increased both its productivity and trade. Moreover, the country has accumulated large amounts of liquidity in the capital market. China's rising trade and investment abroad led to the increased financialization and internationalisation of the renminbi. With Asia seeing high growth and being an economically fast-growing region, this could open the possibility of a regional free trade zone and also the possibility of forming an Asian currency that could be used in trade and as a foreign exchange reserve. Such a development would ultimately undermine U.S. dollar hegemony in the region.

It is estimated that should the current scenario continue, China will overtake the U.S. by 2030 to become the biggest economy in the world. The World Economic Forum (2018) also noted the country's per capita GDP has continued to converge in relation to that of the U.S., although at a moderate rate. However, the country's growth rate has decelerated since 2013 when it grew by $7.7 \%$, declining in subsequent years to $7.3 \%, 6.9 \%$ and $6.7 \%$ in 2014, 2015 and 2016, respectively. In recent years, China has emerged as the biggest foreign buyer of U.S. Treasury bills and U.S. dollars, and will perhaps go on buying to prevent a dollar crash. In order to escape the 'dollar trap', the Chinese government should be worried about the sharp fall in the value of dollar. It is suggested that China has sold around between U.S. $\$ 50$ bn and $\$ 100$ bn U.S. dominated assets each month since 2009 and bought assets such as agricultural land, mines and corporate stocks in Asia, Africa and Europe (Wade, 2009). China is also advancing credits to oil companies in Brazil, Dubai, and Russia, which they will repay in oil.

China was one of the poorest countries in the world before 1980 in a closed economy. However, since the Chinese economic reform of the 1980s, the Chinese economy has been growing rapidly. China's current GDP is nearly 70 times what it was in 1980. The current world is an open economy, wherein the trend towards economic globalization is developing rapidly. Economic globalization not only promotes economic cooperation among countries, but also affects close economic development between countries. Due to different national conditions in China, the direct impact of the international financial crisis on Chinese economic development is relatively small. Chinese GDP seems to keep rising, even when most other countries saw a decline during the global financial crisis. In 2013, President Xi Jinping of China proposed that the "Belt and Road" is becoming an important link for Chinese international trade with the world. China's One Belt 
One Road (OBOR) initiative and the Asian Infrastructure Investment Bank (AIIB) are intended to increase regional trade but also increase the use of the renminbi, as any currency needs to first gain foothold as a regional currency before becoming a global currency (Siddiqui 2019c).

The Chinese currency has become the fifth-largest international currency since 2016, when the International Monetary Fund formally included the renminbi in the SDR basket. The circulation and use of RMB is mainly accompanied by the rise of tourism. China sees a large number of its tourists visiting various countries every year, so there are more and more shops in these countries where the RMB can be used to buy goods. Judging from the current world situation, no country's currency can hope to match the dollar in the near future with the possible exception of the yuan. The euro was the most likely to replace the dollar, but after the 2008 economic crisis, it was somewhat weakened. The financial crisis in the European countries lead to a weaker euro and left them unable to compete with the dollar in terms of international market share. In addition, although the Japanese yen and UK pound are important internationally, the productivities of these two countries are low, making it difficult for either to assume the role of the world's major currency. (Siddiqui 2019b, Subacchi 2016)

China's export clears in renminbi reached $26 \%$ in 2018. Furthermore, with the increasing renminbi deposits around the world, the demands on renminbi financial products have also been increasing in recent years. It is estimated that by 2030, the Asia-Pacific region will account for $40 \%$ of global GDP and two-thirds of the global middle class. China's number of middle class is expected to rise to six hundred million by 2020. (Subacchi 2016) This would mean China and the AsiaPacific will be the largest consumer market for goods. It is also expected that within next few years, due to these changes, the renminbi will become the major trading and clearing currency in the Asia-Pacific region.

China's financial system, fiscal policy and the management of its foreign exchange is in government control and thus the government still maintains macroeconomic autonomy despite the fact that the country is an active participant in the WTO and global financial capitalism (Siddiqui 2015).

\section{Internationalisation of the Renminbi}

Over the last four decades, the renminbi went from being virtually inconvertible to becoming one of the few major recognised global currencies. Although exchange rates have been controlled by the Chinese central bank since 1981, they have gone through different forms of managed convertibility. For example, from 1981 to 1994 , a number of devaluations were enacted to boost exports. Between 1994 and 2005, the renminbi was virtually pegged to the U.S. dollar at a fixed rate. Between 2005 and 2010, this peg shifted to a basket of currencies, and in 2014 the band of fluctuation around the exchange rate target set by central bank was widened. (Subacchi 2016) The internationalisation of the renminbi is being gradually pursued through a number of polices. For instance, control of capital account has been aimed at easing monetary inflows and 
outflows, establishing offshore exchange centres, where foreign institutions can exchange the currency with Chinese banks, whereby China has made a series of currency swaps with trading partners, establishing a mechanism for payment of exports and imports without using the U.S. dollar.

Russia radically decreased its U.S. dollar holdings to very low levels last year, and this is seen as a move to boost renminbi and yen reserves. Russia's central bank more than halved its dollar reserves in 2018 and moved $\$ 44$ bn each into the renminbi and the euro and $\$ 21$ bn into yen (See Figure 4). This move came soon after the U.S. passed sanctions in April, where Seddon notes: "after the passed sanctions in April that knocked 20 per cent off the rouble's value against the dollar and saw investors scramble to cover against future measures that could affect sovereign debt and popular stocks." (Seddon 2019) There seems to be a clear change in Russia's foreign exchange holdings, with a large shift towards the renminbi. Russia had only $0.1 \%$ total reserves in the renminbi in June 2014, which only one year later had risen to $15 \%$. The renminbi holdings yield is $3.20 \%$ compared to $0.35 \%$ for the U.S. dollar.

The Economist (2015: 15) noted about the U.S. dollar that "For 70 years the dollar has been the superpower of the financial and monetary system ... As a means of payment, a store of value and a reserve asset, nothing can touch it. Yet dollar's rule has brittle foundations, and the system it underpins is unstable." The U.S. accounts for $23 \%$ of global GDP and $12 \%$ of merchandise trade. Yet around $60 \%$ of the world's output and a similar share of world's population lie within the dollar zone, i.e., in which currency is pegged to the dollar. The US firm's share of the stock of international corporate investment has fallen from 39\% in 1999 to 24\% in 2015 (Economist 2015).

Figure 4. Currency Composition of Official Foreign Exchange Reserve

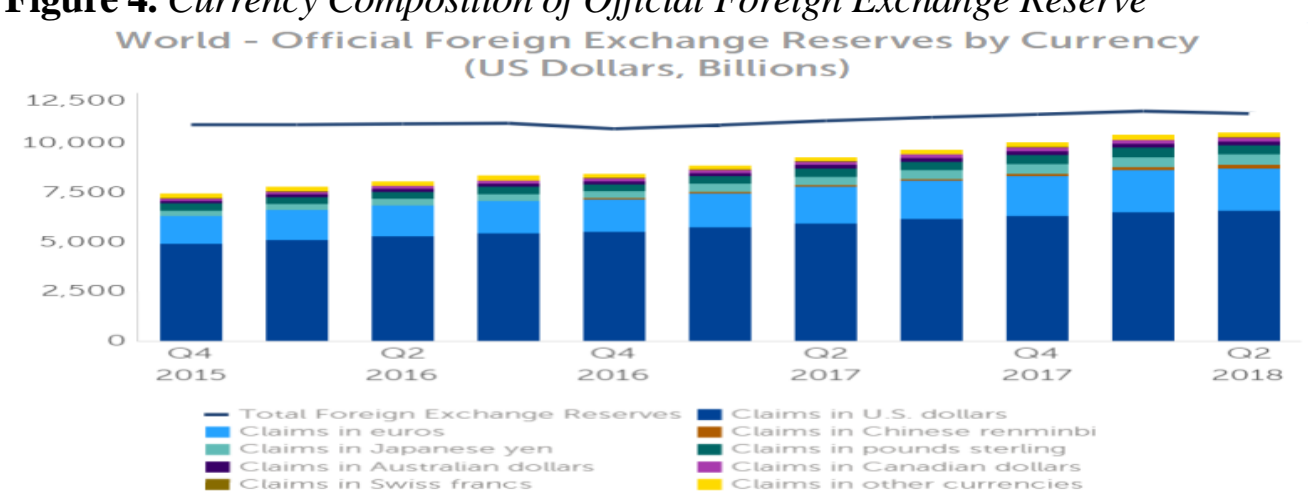

Source: IMF Data. Available at https://data.imf.org/?sk=E6A5F467-C14B-4AA8-9F6D-5A09EC4 E62A4.

In the 1970s, the French government termed the dollar "America's exorbitant privilege". In the light of the 2008 financial crisis, Eichengreen (2011) noted that other countries question whether the U.S. should have been allowed to run current account deficits approaching 6\% of GDP prior to the crisis. Emerging economies are critical in the sense that as their economies expands; they are under pressure to raise dollar reserves for any unexpected eventualities. They are compelled to 
provide cheap finance for U.S. external deficit. The cheap foreign money keeps U.S. interest rates low and thus subsidies the U.S. Eichengreen argued that the inter-war experience was that a reserve currency status can change if a new dominant power emerges. Earlier it was thought that Europe might challenge the dollar's hegemonic role. At present, this looks less likely and the sharp rise of the Chinese economy and the fact that it is now a larger exporter than the U.S., holds massive foreign reserves (in dollars), and its GDP, when converted at the current exchange rate, could match the U.S. by 2025 .

Since the U.S. dollar is the accepted international currency, other countries would naturally like to hold reserves in it. The demand for U.S. assets, primarily Treasury Bonds, is thus higher than it otherwise would have been, thereby lowering interest rates for U.S. borrowing, which Eichengreen estimated to be up to 1 percentage point in the last decade, which is equivalent to an annual benefit of $0.1 \%$ of its GDP. Eichengreen (2011) suggested that there is a strong possibility of a convertible renminbi as early as 2020 . The U.S. is troubled by its continuing balance of payments and budget deficit, and also by mounting foreign and domestic debts. All these would adversely affect the future importance of the U.S. dollar, as happened nearly one hundred ago, when the British Pound Sterling lost its global role due to the weakening of British economy. It is not beyond possibility that the US dollar could experience a similar future. According to Boltho (2011: 147), "There is no doubt, threats to America (not quite) hegemonic position and the U.S. dollar could crash should foreign investors, and primarily China, suddenly lose faith in the currency. But this would not be in no ones' interest. China is the first to realize that a dollar collapse would leave it doubly poorer; its massive U.S. Treasury Bond holding would be worth a good deal less in domestic currency, and its export competitiveness would suffer a huge blow". Eichengreen (2011) predicts a world of multiple international currencies, with the euro and renminbi playing more significant roles at the regional level.

In 2009, China's central bank (the People's Bank of China) began a programme in a few Chinese cities to allow trade to be settled with Hong Kong, Macao and 10 other East Asian countries in renminbi. By 2011, this programme was expanded to an increasing number of Chinese cities and, indeed, to additional countries. As a result, there was a sharp rise in trade from 3 bn renminbi to 535 bn renminbi in 2010 and to total of 2.1 trillion renminbi by 2012. China also has signed currency swap agreements with 20 countries, and it is hoped that such agreements will further increase the use of the renminbi. Jenkins and Zelenbaba (2012: 523) note: "Over 3-5 years, overseas lending in RMB would be further accelerated, with restrictions on investment in Chinese property, stock and bond markets gradually being eased as financial sector development strengthened over 5-10 year period... The process would eventually culminate in a fully convertible RMB, suggestive of the fact that Chinese officials remain steadfast, however, cautious, along the course of internationalizing their currency".

Despite the use of the renminbi rising in recent years, it still does not have the particular advantage of the US dollar which is its ability to profit from the global markets. However, as China's financial assets are more internationalised, the more Chinese economy is financialised. In fact, whilst the OBOR initiative will help 
China to find markets for its excessive production capacity, it will also help to achieve economies of scale and to build the comparative advantage of globally competitive markets (Siddiqui 2019c). The government facilitates OBOR and outflows of Chinese capital to invest in new markets overseas. The country must build regional institutional arrangements in finance and currency exchange, as the U.S. did soon after the Second World War, which is known as the Bretton Woods system. Such a move facilitated U.S. exports of goods into international markets. China attempts to build AIIB and also other institutional arrangements relating to exchange agreements between the renminbi and other regional currencies. Such measures would build a non-U.S. trading clearing system. Furthermore, such a large infrastructural project would require credit creation, financing and clearing tasks, but the risk is that such huge profits may drive the financial sector to overexpand and over-stretch itself in an attempt to create quality renminbi-based financial assets (Hung 2013). Over-expansion of the financial sector may have an adverse impact on the real economy, leaving it vulnerable to financial crisis as happened in the 2008 subprime bubble in the U.S. and Europe.

\section{Conclusion}

Ten years ago, the financial crisis in the United States led to a global economic crisis in 2008. This financial crisis was caused by the exposure of risks in the U.S. house market, which led to a nearly vertical downward in the U.S. dollar index. Emerging economies have been affected by the severity of the global economic financial shocks because the current global reserve system fails to ensure adequate international liquidity (Lee 2014). The recent years, a growing disappointment with the functioning of the international financial system and with the U.S. dollar remaining dominant in facilitating the build-up of global current account imbalances has been seen (Mason 2018); this was the case even before the 2008 crisis. At the same time, the Chinese accumulation of dollar assets and its rapidly growing trade and participation in the global economy, and also the increase in the use of the renminbi in trade, indicates significant impending change in the world economy. With the rapid slowdown of the performance of the U.S. economy and trade, there are concerns being raised about the dollar as the single dominant reserve currency and the asymmetry in adjustments to shocks. There is no mechanism for adjustment, especially real exchange rate adjustment in surplus countries (Jenkins and Zelenbaba 2012).

It seems that Kaldor is describing the current state of US economy rather than nearly 50 years ago. As Nicholas Kaldor noted: "The persistent large deficits in the United States balance of payments-given the universal role of the dollar as the medium for settling inter-country debts-acted in the same way as a corresponding annual addition to gold output... So long as countries preferred the benefits of fast growth and increasing competitiveness to the cost of part-financing the United States deficit and so long as a reasonable level of prosperity in the United States could be made consistent with the increasing uncompetitiveness of United States goods in relation to European and Japanese goods, there was no reason why any 
major participants should wish to disturb these arrangements" (as cited in D'Arista 2009: 645). According to him but as the US products were displaced by other countries both in US and overseas market and to maintain prosperity would require budget and balance of payment deficits. Few years later he notes, "If continued long enough it would involve transforming a nation of creative producers into a community of rentiers increasingly living on others, seeking gratification in ever more useless consumption, with all the debilitating effects of the bread and circuses of Imperial Rome..." (as cited in D'Arista 2009: 645).

The Study has found that the U.S. dollar still accounting for two-thirds of all foreign exchange reserves and the United States' ability to run large current account deficits has turned out to be a calamity. Once the dollar loses its status as an international currency, there is no doubt that the dollar will depreciate substantially. The United States will be unable to repay its external debt. China as the largest American creditors will lose a lot of money.

This article concludes that the U.S. economy is currently suffering from a serious trade deficit and the position of the U.S. dollar is under genuine threat from the renminbi, the renminbi will not be able to replace the U.S. dollar as the global currency for at least the next decade. However, the next 10-15 years may well see the coexistence of Chinese currencies with the U.S. dollar, especially in the Asian region. It may take at least 20-30 years before there is a real possibility of replacing the U.S. dollar.

The study suggests that the policy should be set to seek profit in the real economy rather than 'finance financing finance'. Finance should be made less globalised. In fact, the pressing issue in dealing with global imbalances is to find ways to recycle the saving of surplus economies back into their own economies to be invested in developmental projects which would increase demand and income and create employment and will also make them less dependence of export-led growth. In the U.S., there is a need to increase public spending rather than rely on debt-fuelled private consumption to resolve inadequate aggregate demands. Greater investment in skills and education will increase labour productivity which will positively impact profit rates, as occurred during the post-war period under regulated capitalism, while rising wages, consumer and government spending would result in higher investment and capacity utilisation.

\section{Acknowledgments}

The author is grateful to Hugo Radice, and John Smith for helpful suggestions and general discussions related to the topic. The author would also like to thank two anonymous referees of this journal for helpful comments, which definitely has helped to improve the article. 


\section{References}

Amadeo K (2018) Donald Trump's Economic Plan: How President Trump Is Changing the Economy. Retrieved from www.thebalance.com. [Accessed 11 January 2018].

Boltho A (2011) The dollar era. New Left Review 145(November-December): 145-51.

Bullard S, Silvia JE and Iqbal A (2017) Can We Estimate the Cost of a Recession? American Economic Association Conference. Available at https://bit.ly/2EeidER.

Costigan T, Cottle D and Keys A (2017) The US dollar as the global reserve currency: implications for US hegemony. World Review of Political Economy 8(1): 104-122. Available at https://bit.ly/2Qb4cMV.

D'Arista J (2009) The Evolving International Monetary System. Cambridge Journal of Economics 33(4): 633-652.

Delivorias A (2016) Understanding Securitisation: Background, Benefits, Risks. European Parliament Research Service, PE569.017. Available at https://bit.ly/2Js22rY.

Economist (2015) Dominant and Dangerous, 3 October, pp. 15, London.

Eichengreen B (2011) Exorbitant Privilege: The Rise and Fall of the Dollar. Oxford: Oxford University Press.

Fine B (2013) Financialization from a Marxist Perspective. International Journal of Political Economy 42(4): 47-66.

Glyn A (2005) Imbalances of the Global Economy. New Left Review 34: 5-37.

Harvey D (2005) A Brief History of Neoliberalism. Oxford: Oxford University Press.

Huang A, Kishor NK (2019) The rise of dollar credit in emerging market economies and US monetary policy. The World The World Economy 42(2): 530-551.

Hung H-F (2013) China: saviour or challenger of the dollar hegemony? Development and Change 44(6): 1341-1361.

IMF (2019) Currency Composition of Foreign Exchange, IMF. Data. Retrieved from https://bit.ly/2VDDtK0. [Accessed 22 February 2019].

Jenkins P and Zelenbaba J (2012) Internationalization of the Renminbi: What it means for the stability and flexibility of the international monetary system. Oxford Review of Economic Policy 28(3): 512-531.

Kaldor N (1971) The Dollar Crisis. The Times, p. 6, 8 September, London.

Keynes JM (1980) The Collected Writings of John Maynard Keynes, Volume XXV: Activities 1940-1944: Shaping the Post-War Economy. London: Macmillan.

Kotz D (2018) End of Neoliberal Era? New Left Review 113(September-October): 29-55.

Krugman P (2007) Will there be a Dollar Crisis? Economic Policy, 435-467. Simon Fraser University. Available at: https://www.sfu.ca/ kkasa/Krugman_07.pdf.

Lee J-W (2014) Will the Renminbi Emerge as an International Currency?. The World Economy 37(1): 42-62.

Mason JM (2018) What Is the U.S. Dollar Saying About The Economy? Retrieved from https://seekingalpha.com/article/4183256-u-s-dollar-saying-economy. [Accessed on 17 May 2019]

Norfield T (2016) The City: London and the Global Power of Finance London: Verso.

OECD (2019) International Direct Investment Statistics. Paris: OECD. Retrieved from https://www.oecd-ilibrary.org/finance-and-investment/oecd-international-directinvestment-statistics_2307437x. [Accessed 10 February 2019].

OECD (2019) Main Economic Indicators: Balance of Payments. Paris: OECD Retrieved from https://data.oecd.org/trade/current-account-balance.htm. [Accessed 10 February 2019]. 
OECD (2019) United States Long Term Interest Rates. Paris: OECD. Data. Retrieved from https://data.oecd.org/interest/long-term-interest-rates.htm. [Accessed on 10 February 2019].

OECD (2019) Real GDP Long-term Forecast, Total, Million US Dollars, 2020 - 2040. Retrieved from https://data.oecd.org/gdp/real-gdp-long-term-forecast.htm. [Accessed on 2 March 2019].

Patnaik P (2009) The Value of Money. New York: Columbia University Press.

Seddon M (2019) Russia Ditches Dollar Holdings to Foil US Sanctions and Boost Renminbi Reserves. Financial Times, 11 January, London. Retrieved from https://www.ft.com/ content/4f599984-14da-11e9-a581-4ff78404524e. [Accessed on 28 February 2019].

Siddiqui K (2015) Perils and challenges of Chinese economic development. International Journal of Social and Economic Research 5(1): 1-56.

Siddiqui K (2016a) Will the growth of the BRICs cause a shift in the global balance of economic power in the 21st Century? International Journal of Political Economy 45(4): 315-338.

Siddiqui K (2016b) International trade, WTO and economic development. World Review of Political Economy 7(4): 424-450.

Siddiqui K (2017) Financialization and economic policy: the issues of capital control in the developing countries. World Review of Political Economy 8(4): 564-589.

Siddiqui K (2018a) U.S. - China Trade War: The Reasons Behind and its Impact on the Global Economy" The World Financial Review, November/December, pp.62-68. ISSN 1756-3763. Available at https://bit.ly/2Yynkrm.

Siddiqui K (2018b) The political economy of India's economic changes since the last century. Argumenta Oeconomica Cracoviensia, No.19: 103-132. ISSN: 1642-168X. e-ISSN: 2545-3866. Available at: https://doi.org/10.15678/AOC.2018.1906.

Siddiqui K (2018c) The political economy of India's post-planning economic reform: a critical review. World Review of Political Economy 9(2): 235-264.

Siddiqui K (2019a) A Perspective on Productivity Growth and Challenges for the UK Economy. Submitted for the Athens Journal of Business and Economics.

Siddiqui K (2019b) Government debts and fiscal deficits in the UK: A Critical Review. World Review of Political Economy, forthcoming, vol. 10.

Siddiqui K (2019c) one belt and one road, China's massive infrastructure project to boost trade and economy: An Overview. International Critical Thought, forthcoming, vol. 9.

Stiglitz J and Greenwald B (2010) Towards a new global reserve system. Journal of Globalisation and Development 1(2): 1-25.

Subacchi P (2016) The People's Money: How China is Building a Global Currency. New York: Columbia University Press.

Wade R (2009) From global imbalances to global reorganisations. Cambridge Journal of Economics 33(4): 539-562. DOI: 10.1093/cje/bep032.

Wade R (2017) The American paradox: ideology of free markets and the hidden practice of directional thrust. Cambridge Journal of Economics 41(3): 859-880. DOI: 10.1093/cje/bew064.

Wien B (2010) US Capital Productivity Decline Must be Reversed. Financial Times, p.34, 17 February 2010, London.

Willett TD and Chiu EMP (2012) Power relations and the political economy of global imbalances. Global Economic Review 41(4): 341-360.

Wolf M (2008) Comments on global imbalances. Financial Times, p. 13, 7 October, London.

World Bank (2017) Global Economic Prospects: A Fragile Recovery, June. World Bank: Washington DC. 
World Economic Forum (2018) What China's Period of Rapid Growth Means for the Rest of the World. Retrieved from https://www.weforum.org/focus/davos-2018. [Accessed 2 March 2019]. 
